\title{
SPINAL CORD INVOLVEMENT IN SYSTEMIC LUPUS ERYTHEMATOSUS
}

\author{
By H. J. Hachen ${ }^{1}$ and A. Chantraine ${ }^{2}$ \\ 1 Spinal Cord Injury Centre; ${ }^{2}$ Institute of Rehabilitation Medicine, Geneva University \\ Hospital, CH-I2II Geneva 4, Switzerland.
}

Abstract. A review is made of the literature on central nervous system involvement in systemic lupus erythematosus (CNS-SLE). Particular attention is focused on lupus myelopathy. Referring to two well-documented personal cases, the authors describe the characteristic multisystem involvement, protean clinical pattern, serum and cerebrospinal fluid changes, histoimmunologic findings, response to corticosteroids and immunosuppressive agents and some prognostic features.

Key words: Systemic lupus erythematosus; Transverse myelitis; Autoimmune disease; Corticosteroids; Immunosuppressive agents.

SYSTEMIC lupus erythematosus may be considered the prototype of human autoimmune disease. As such it has an exceptionally wide spectrum of clinical manifestations. Virtually any system may be involved: migratory, non-deforming arthralgia, erythematous scaly rash on face, neck and elbows, hepato-splenomegaly, generalised lymphadenopathy, Libman-Sacks endocarditis, pleuritis, peritonitis and multiple manifestations of central and peripheral nerve lesions are some of the commonly encountered features of this disease (Table I).

The co-existence of several of the above-mentioned symptoms in patients presenting relevant laboratory findings such as positive LE cell preparations, hypocomplementemia, HLA-B ${ }_{8}$ constellation, increased titer of antinuclear antibodies and lymphocytotoxic antibodies should leave no doubt with regard to diagnosis. In its more atypical and oligosymptomatic expressions, however, SLE may, at times, be difficult to distinguish from periarteritis nodosa, multiple sclerosis, rheumatoid arthritis, dermatomyositis, etc. (Lipton \& Teasdall, 1973; Cendrowski \& Stepien, 1974; April \& Vansonnenberg, 1976).

\section{Central Nervous System Lupus Erythematosus (CNS-SLE)}

Involvement of the central nervous system in SLE patients is a rather common finding. Quite similar to syphilitic nerve damage there also exists a large variety of clinical expressions. The incidence of neuropsychiatric disorders reported in the literature varies between Io and 60 per cent, depending on the length of follow-up, thoroughness of neurological examination and mode of treatment (Bas \& Vachtenheim, 1963; Berry \& Hodges, 1965).

The occurrence of mental disorders in SLE patients had already been reported by Hebra and Kaposi in 1875. Hemiplegia and aphasia were described by Osler in 1903. Daly, in 1945, described a state of 'toxic delirium' with prostration, anxiety, irritability and disorientation in several of his SLE patients. A full account of the large range of neuropsychiatric manifestations was presented by Sedgwick and Von Hagen in I948. Three years later Russel, Haserick and Zucker (I95I) reported severe episodes of seizures in I 5 per cent of a series of I44 patients. 


\section{TABLE I}

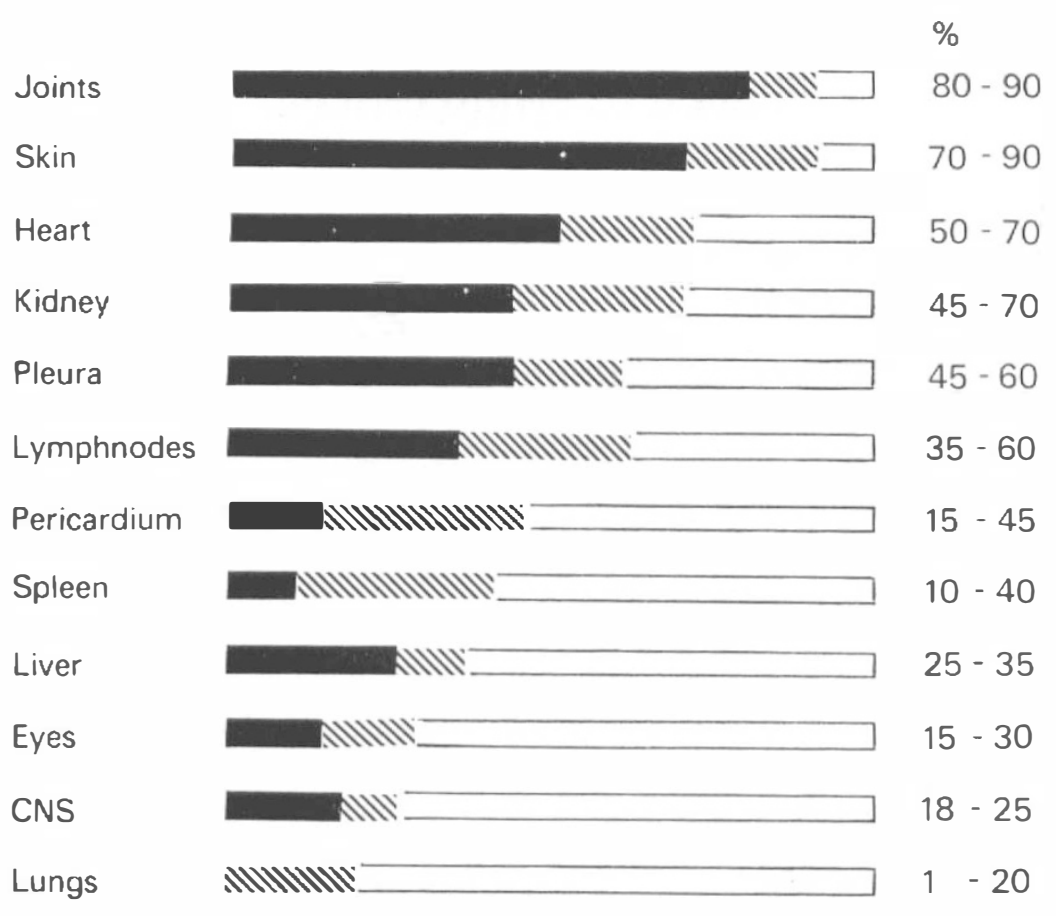

In I952 Heptinstall and Sowry presented the first detailed paper on peripheral neuritis. Weil, in I955, published a well-documented case report on subarachnoid haemorrhage. Scheinberg, in 1956, drew attention to the rare occurrence of Guillain-Barré-like symptoms.

In the recent literature cranial nerve involvement is mentioned in approximately I 5 to 20 per cent. Chorea is exceptional. Bennahum and Messner (1975), reviewing the literature on this subject, found only 29 cases. Brandt and Lessell (1978) state that migrainous phenomena, such as throbbing headache of hemicranial onset and visual hallucinations, are frequently observed during exacerbations of SLE. In periods of remission these symptoms spontaneously disappear. These authors also indicate that corticosteroids are more effective in bringing about relief than conventional antimigraine therapy.

Approximately one-third of all patients with CNS involvement show psychotic depressive reactions. Less frequently catatonic, paranoid and manic states are observed. Bennahum and Messner (1975) detected organic psychiatric symptoms (delirium, hallucinations, etc.) in 16.6 and functional psychiatric symptoms (depression, anxiety, etc.) in 53.7 per cent of a series of 54 patients with CNSSLE. Sergent, Lockshin and Klempner (1975) state that functional psychoses are likely to become aggravated by high-dose corticosteroids. They suggest that minimal effective doses should be administered in combination with psychotropic drugs.

Central nervous system involvement occurs typically at a moment of acute exacerbation of lupus erythematosus. O'Connor and Musher (I966) state that only very few patients on ambulant care exhibit signs of CNS involvement. 
PAPERS READ AT THE ANNUAL SCIENTIFIC MEETING, I978

TABLE II

Incidence of Neurologic and Psychiatric Disorders in SLE

\begin{tabular}{lcccc}
\hline \multicolumn{1}{c}{ Author } & Year & Number & Neurologic & Psychiatric \\
\hline Harvey & I954 & I05 & I7\% & I9\% \\
Clarke/Bailey & I956 & IOO & $14 \%$ & $17 \%$ \\
Armas-Cruz & I958 & I08 & $8 \%$ & $36 \%$ \\
Rupe/Nickel & I959 & I00 & $7 \%$ & $3 \%$ \\
Stern/Robbins & I960 & 53 & $23 \%$ & $50 \%$ \\
Bennet & I961 & 45 & $18 \%$ & $18 \%$ \\
O'Connor/Musher & I966 & I50 & $17 \%$ & $29 \%$ \\
Johnson & I968 & 24 & $75 \%$ & $33 \%$ \\
Heine & I969 & 38 & $13 \%$ & $44 \%$ \\
Estes & I97I & I50 & $48 \%$ & $42 \%$ \\
Hadler & I973 & 35 & $17 \%$ & $9 \%$ \\
Bennahum & I974 & 54 & $57 \%$ & $59 \%$ \\
\hline
\end{tabular}

Exceptionally CNS disorders may be the first clinical manifestation of LE. Silverstein (1963) described five cases with an 'acute cerebral insult' as initial symptom of SLE. Krankenhagen, Cohnen and Lehmann (1975) also described severe neurological disorders as initial clinical expression of LE (Table II).

\section{Diagnosis}

It may at times be difficult to decide whether neuropsychiatric symptoms are directly related to SLE (Stern \& Robbins, I960) or rather a consequence of long-term therapy with corticosteroids or of severe nephropathy. When reviewing the literature we found that early diagnosis of CNS-SLE was very frequently mistaken. This emphasises the diagnostic value of additional information that may be derived from recently developed techniques such as histoimmunology (Johnson \& Richardson, I968).

\section{Laboratory investigations}

Cerebrospinal fluid: in the acute stage of CNS-SLE, CSF shows pleocytosis (rarely exceeding 200 cells $/ \mathrm{mm}^{3}$ ) and moderately increased protein. These changes, however, do not reflect the severity of the disease nor do they have prognostic value. In the acute stage of $\mathrm{CNS}$ involvement the titers of CSF-C4 (complement component 4) and CSF IgG are often significantly decreased (Petz, Sharp \& Cooper, I97 ; Levin, Findenberg \& Petz, I972; Hadler, Gerwin \& Frank, 1973). This clearly speaks in favour of a direct implication of immune mechanisms in CNS manifestations of LE. The fact that antineuron antibodies may be isolated in 40 per cent of patients with central nervous involvement, but only in Io per cent in patients without neurological signs further corroborates this concept.

Serum studies: during clinical exacerbations of SLE the complement component $\mathrm{C}_{3}$ is frequently decreased. Concomitantly one observes high titers of circulating antinuclear antibodies and DNA/anti-DNA immune complexes. It is now thought that the latter may be trapped in the basement membrane of the choroid plexus where complement fixation may ensue (Burton, Duffie \& Mudler, I97I). 
In recent years several authors have reported significantly increased levels of antiviral antibodies in LE patients without parallel changes in total serum IgG, $\operatorname{IgA}$ and IgM. This observation is compatible with a humoral hyperresponsiveness of SLE patients to a variety of viral antigens such as parainfluenza II and III and influenza $\mathrm{A} 2$ and $\mathrm{B}$.

Other findings which will require further studies are the unexpectedly high incidence of lymphocytotoxic antibodies in most SLE patients and their relatives and the marked decrease or suppression of $\mathrm{T}$-cell function. In fact, a disequilibrium of thymus-dependent ( $\mathrm{T}$ ) and bone-marrow-dependent (B) lymphocyte function may well trigger some of the complex immunologic abnormalities in SLE patients.

With regard to histocompatibility it has been found that HLA-B ${ }_{8}$ is prevalent in 40 per cent of SLE patients as compared to 20 per cent in healthy controls.

Electroencephalography: the frequently recorded dominant beta-wave is compatible with diffuse encephalopathy; there exists, however, no direct correlation with the clinical symptomatology. Small, Mass, Kohler and Harbeck (I977) observed altered EEG pattern in about 80 per cent of their LE patients.

Brain scan: this technique is useful in identifying patients with decreased cerebral vascular flow and in distinguishing them from cases with steroid psychosis and functional mental disorders. Abnormal flow brain scans are obtained in about 50 per cent of LE patients with CNS involvement (Bennahum, Messner \& Shoop, I974; Small et al., 1977).

\section{Pathology}

The histopathological studies reveal multiple small infarcts or haemorrhages with perivascular gliosis. An embolic aetiology can usually be excluded. The lesions are essentially confined to the cortex and brain stem. There exists a rather poor correlation between the clinical symptoms and anatomo-pathologic findings. Thus, some patients with minimal neuropsychiatric disorders have widespread CNS involvement and vice versa (Gold \& Yahr, I960).

\section{Prognosis}

Spontaneous remission may be observed in as much as 40 per cent of the patients. In this context it appears difficult to assess the efficacy of drug therapy and to propose guide-lines for optimal dosage regimes of corticosteroids and immunosuppressive agents.

The prognosis of patients with neuropsychiatric signs depends essentially on the extent and severity of multiorgan disease. On the average three other systems are involved. Lupus nephritis, present in two-thirds of the patients, has long been the major cause of death. Since haemodialysis has become available, the average survival of patients with CNS-SLE now closely approaches the Io years' limit and death now frequently results from CNS damage.

\section{Transverse Myelopathy}

This manifestation of central nervous system involvement is very rare. Until today I 8 authors have reported a total of 26 cases (see Table III). Spinal cord damage occurs mostly at a time of acute exacerbation of LE (Andrews, Cancilla \& Kunin, I970; Castaing, Vital \& Cardinaud, 1970). Onset is usually rapid, within a few hours. The most common neurological level is mid-thoracic (about 
TABLE III

SLE with spinal cord involvement

\begin{tabular}{|c|c|c|}
\hline Author & Year & Cases \\
\hline Fischer, J. H. & I939 & I \\
\hline Piper, P. G. & 1953 & I \\
\hline Siekert, R. G. et al. & 1955 & I \\
\hline Weil, M. H. & 1955 & I \\
\hline Clark, E. C. et al. & 1956 & 2 \\
\hline Scheinberg, L. & 1956 & I \\
\hline Armas-Cruz et al. & 1958 & I \\
\hline Granger, D. P. & 1960 & I \\
\hline Johnson, R. T. & 1962 & I \\
\hline Bas, H. et al. & 1963 & 2 \\
\hline Penn, A. S. et al. & 1968 & 4 \\
\hline Castaing, R. et al. & 1970 & I \\
\hline Hadler, N. M. et al. & 1973 & 2 \\
\hline Lipton, H. L. et al. & 1973 & I \\
\hline Cendrowski, W. et al. & 1974 & I \\
\hline Andrianakos, A. A. et al. & 1975 & 2 \\
\hline Sergent, J. S. et al. & 1975 & I \\
\hline Small, P. et al. & I977 & 2 \\
\hline I 8 authors & & 26 cases \\
\hline
\end{tabular}

60 per cent) and the large majority of these patients present complete and irreversible paraplegia (Penn \& Rowan, I968). In the remaining group of patients cervical and lumbar myelomalacia are about equally frequent and often cause only partial motor and sensor loss (Piper, 1953; Andrianakos, Duffy \& Suzuki, 1975).

Occasionally transverse myelitis is the first manifestation of lupus erythematosus. Granger (1960) reported a case of sudden transverse myelitis in a 25year-old female who was treated with chloroquine and recovered completely within 4 months. In a case described by Siekert and Clark (1955), acute myelopathy also was the initial evidence of SLE; other systems became involved 2 years later only.

Cortisone treatment does not affect the course of lupus myelopathy but may induce prolonged remissions in other systems, particularly in combination with azathioprine.

Post-mortem examination reveals multiple small zones of myelomalacia in both the grey and white matter; arterioles may show some degree of fibrinoid degeneration. LE-specific lesions have not been described in the central nervous system. In evaluating the anatomopathological picture one should consider the possible changes induced by prolonged corticosteroid treatment.

\section{Case Report}

I. Z. A. (CP. 300803). This male patient, born in 1930, enjoyed excellent health until the age of 28 when he presented typical signs of Raynaud's syndrome. In 1962 he therefore consulted the department of angiology. Preganglionic sympathectomy was proposed but rejected by the patient. During summer 1964 he showed severe fatigue, 
anorexia, weight loss of $4.5 \mathrm{~kg}$ within 3 months. In October he was hospitalised for full investigations.

Upon admission the patient was irritable and lethargic, complained of vertigo, throbbing headache and diffuse myalgia. Temperature was $39 \cdot 4^{\circ} \mathrm{C}$. Physical examination revealed no sign of skin rash, arthritis or petechiae. The liver was slightly enlarged and tender, but there was no splenomegaly nor lymphadenopathy. Cardiac auscultation disclosed a soft apical systolic murmur; the ECG indicated flat T-waves. Roentgenograms of the chest revealed slight pleural thickening. A barium enema, i.v. pyelogram and sinus X-ray films were normal. Malignancy could be ruled out. Laboratory investigations showed a markedly accelerated sedimentation rate of $98 /$ I I 5 ; haemoglobin was $9 \cdot 2 \mathrm{~g}$. Blood chemistry was unremarkable. ANA-titer was positive at I60; a complement fixation test with DNA was also strongly positive. LE cells could not be identified. Kidney biopsy demonstrated typical lupus nephritis with 'wire-loop' changes in the glomerular tufts. Prednisone treatment was started at an initial dosage of $80 \mathrm{mg}$ per day and subsequently tapered to Io mg per day.

Six months later, in April 1965, the patient again complained of vertigo and severe left hemicranial headache; neurological examination showed marked pyramidal signs. Latex test was positive. Within the next 6 months the neurological syndrome gradually worsened in spite of high dose prednisone and Imuran. In October I965 a scaly erythematous rash developed on the face and elbows; a skin biopsy showed typical lupus involvement. The following year, in early June, the patient had another exacerbation. He was at that time febrile at $39.6^{\circ} \mathrm{C}$, complained of minor visual disturbances, numbness and extreme fatigability in both lower extremities and difficulty in voiding. Within 8 hours of admission he developed paraplegia with a mid-thoracic sensory level. There was no sign of meningeal irritation; cerebellar function and cranial nerves were normal. Neurologic examination demonstrated marked hyperreflexia in both lower extremities with bilateral extensor plantar response; sensation of pin, touch, vibration and position below $\mathrm{T}_{5}$ was abolished. CSF analysis disclosed pleocytosis $\left(430\right.$ elements $/ \mathrm{mm}^{3}$ ), increased protein ( $128 \mathrm{mg} / \mathrm{I} 00 \mathrm{ml}$ ) and normal glucose. Treatment consisted of prednisone $20 \mathrm{mg}$ daily, combined with alternate courses of Imuran and Methotrexate. With this medication the patient entered a stage of remission; however, his neurological deficit remained unchanged. In December 1967, 18 months after spinal cord involvement, LE cells were identified for the first time.

Until 1974 the patient remained in a state of remission, with occasional burst of fever, intermittent urinary infections and two episodes of arthralgia in both wrists and elbows. In February he was rehospitalised because of severe dyspnea which was considered to be due to lupoid pleuritis. Physical examination revealed a dilated bladder of $1600 \mathrm{ml}$ capacity. Urodynamic investigations confirmed the diagnosis of unbalanced automatic neurogenic bladder in a state of severe chronic retention. The latter was attributed to repeated overdilation of the detrusor and concomitant functional bladder outlet obstruction. In view of these findings we initiated treatment with a cholinesterase inhibitor (distigmin bromide, $3 \times 5 \mathrm{mg}$ per day) in combination with an alpha-adrenergic inhibitor (phenoxybenzamine, $4 \times 10 \mathrm{mg}$ per day). Control cystosphincterometry, carried out 3 months later, showed non-inhibited detrusor contractions of 40 to 60 $\mathrm{cmH} 20$ and post-micturition residuals between 60 and $100 \mathrm{ml}$. Dyspnea had entirely disappeared and spirometry indicated a vital capacity of $3150 \mathrm{ml}$ and a maximal expiratory volume/second of $1620 \mathrm{ml}$. The patient was dismissed and remained fairly well until September 1975 when he developed severe seizures and entered a deep comatous state which persisted for several hours. When he regained consciousness he presented typical Cheyne-Stokes breathing and a left conjugate deviation of the head and the eyes. CSFanalysis disclosed $128 \mathrm{mg}$ of protein/100 $\mathrm{ml}, 265 \mathrm{WBC} / \mathrm{mm}^{3}$ (59 per cent segmented and 27 per cent non-segmented neutrophils); culture was sterile. Serum anti-DNA antibodies and direct Coombs' test were strongly positive.

Beta-I-C-globulin was $33 \mathrm{mg}$ per cent and kidney biopsy showed marked glomerular deposits of immunoglobulin. Isotope clearance studies indicated a glomerular filtration rate of $94 \mathrm{ml} / \mathrm{min} / \mathrm{r} \cdot 73 \mathrm{~m}^{2}$ and a renal plasma flow of $406 \mathrm{ml} / \mathrm{min} / \mathrm{r} \cdot 73 \mathrm{~m}^{2}$. Over the 
following 3 weeks the patient gradually improved. In September 1975 he was admitted to the department of rehabilitation medicine. Since that time he has suffered no further complications.

2. O. Y. (CP. 450109). In September 1964, at the age of 19, this female patient experienced sudden weakness in both legs with gradually intensifying sensor disturbance and loss of sphincter control. Upon admission physical examination was compatible with the diagnosis of Guillain-Barré syndrome. ESR was $60 / 107 \mathrm{~mm}$. CSF revealed moderate pleocytosis; protein and glucose were within normal limits. In December of the same year the girl developed a circumscribed alopecia in the occipital region. She was put on corticosteroids and recovered nearly normal neurological function. In February I 965 the diagnosis of lupus erythematosus was clinically established and confirmed by the finding of abundant LE-cells on three occasions, a significantly increased titer of antinuclear antibodies and concomitant hypocomplementemia. Prednisone was increased to $80 \mathrm{mg}$ per day. Within 5 weeks motor strength in both legs considerably improved. Sensation to pin, touch and vibrations was normal. In January 1969 recurrent attacks of painful swelling were observed in several joints, the wrists and knees being mainly affected. Progressive muscle wasting and general fatigue further characterised the clinical picture. Urinary retention was diagnosed 2 days later. Erythematous scaly patches developed on face, neck and both elbows. The abdomen was found very tender on palpation. Within 5 hours after admission to the emergency department the patient complained of numbness and tingling in both feet which rapidly spread to the thighs and abdomen. Within less than an hour complete flaccid paraplegia was diagnosed. The following day both upper extremities became involved. The girl complained of visual difficulties, had a slight convergent strabism and a horizontal nystagmus. CSF pressure was $40 \mathrm{cmH} 2 \mathrm{O}$; there was marked pleocytosis of 1600 elements $/ \mathrm{mm}^{3}$, mostly polynuclears. Protein was moderately increased, glucose normal and culture sterile. Serum analysis revealed anti-DNA antibodies at a titre of $1 / 8$ and hypocomplementemia. ESR was $50 / 84 \mathrm{~mm}$.

A gaz myelography was carried out 12 hours after admission and disclosed no pathological findings. Kidney biopsy confirmed the diagnosis of lupus nephritis. Treatment consisted of intraspinal administration of $50 \mathrm{mg}$ of Imuran (azathioprine) and Io $\mathrm{mg}$ of Methotrexate (amethopterine). Prednisone was administered at a dose of Io to $20 \mathrm{mg}$ per day. The cranial nerve disorders totally subsided, but complete flaccid paraplegia below $T_{5}$ remained unchanged. The subsequent follow-up remained uneventful but was complicated by multiple pressure sores on the sacrum and both buttocks. Plastic surgery was necessary on three occasions. In 1973 a check-up still showed high titres of anti-DNA antibodies, but LE-cells could no longer be identified. A chest Xray revealed bilateral aseptic osteonecrosis of the head of the humerus. Otherwise the patient was in satisfactory general condition. The autonomous neurogenic bladder had so far caused no complication; the patient was continent and had sterile urine. Within the past four years there have been no acute exacerbations. Prednisone treatment is presently continued at a low maintenance dose of $3 \mathrm{mg}$ per day.

\section{Conclusions}

There have been three major milestones in the understanding and management of systemic lupus erythematosus.

The first one, Hargrave's description of the LE-cell preparation in I948, greatly contributed to improved diagnosis; the second, introduction of corticosteroids in the early fifties, had a considerable impact on the clinical manifestations and prognosis; the third, recognition of the autoimmune character of the disease and identification of various immune complexes within the vessel walls of several organ systems, largely contributed to better understanding of the pathogenesis. 
Due to early diagnosis, comprehensive management and prevention of complications, such as urinary infection and pressure sores, the survival rate of SLE patients has considerably improved within the last decade. CNS involvement, which is known to occur in the later stages of SLE, is therefore likely to be diagnosed with increasing frequency. In fact, the morbidity and mortality due to central nervous system damage now closely approach the ones of lupus nephritis. Spinal cord involvement remains exceptional. These patients should benefit from the same nursing care which we offer to cases with traumatic lesions, especially with regard to neurogenic bladder training, prevention of pressure sores and respiratory therapy.

\section{SUMMARY}

Neurologic and psychiatric disorders are present in approximately 30-40 per cent of patients with disseminated lupus erythematosus. CNS involvement is second only to uremia as a cause of death. Seizures are the single most common symptom (I 5 per cent). Spinal cord lesions are exceptional. So far 26 cases have been reported by 18 authors. Life-expectancy of SLE patients has considerably improved within the last decade as a result of early diagnosis and combined therapy with corticosteroids and immunosuppressive agents. Renal death may now be prevented by dialysis. Therefore an increasing proportion of patients enter the late stage of the disease, where CNS-involvement is a common finding. We emphasise the need for early hospitalisation of patients with spinal cord involvement in a specialised unit where turning beds, intermittent catheterisation and comprehensive motor rehabilitation are available.

\section{RÉSUMÉ}

Des perturbations d'ordre neurologique ou psychiatrique s'observent chez $30-40 \%$ des patients atteints d'un lupus érythémateux disséminé. Les lésions du système nerveux central occupent le deuxième rang parmi les causes de mortalité, immédiatement après l'insuffisance rénale par glomérulopathie lupique. Les convulsions épileptiformes sont le symptôme le plus courant $(15 \%)$, l'atteinte de la moelle épinière est exceptionnelle. Jusqu'à ce jour, 26 cas seulement ont été rapportés dans la littérature par I 8 auteurs. L'espérance de vie des sujets atteints de lupus érythémateux s'est considérablement améliorée au cours de la dernière décennie grâce aux nouveaux moyens d'exploration de laboratoire permettant un diagnostic précoce et à l'introduction d'une thérapeutique combinée associant les corticostéroides aux agents immunosuppresseurs. Dans ce contexte, une proportion accrue de patients entre dans la phase tardive de la maladie au cours de laquelle les lésions du système nerveux central sont particulièrement fréquentes.

Nous insistons sur l'importance d'une hospitalisation précoce des sujets atteints de myélopathie LE dans un service spécialisé, afin d'éviter le crotège des complications (escarre, infection urinaire, etc.) et d'assurer un programme de rééducation fonctionnelle optimal.

\section{ZUSAMMENFASSUNG}

Neurologische Ausfälle und psychiatrische Erscheinungen werden bei etwa 30 bis $40 \%$ von Patienten mit Lupus erythematodes beobachtet. Läsionen der Zentralnervensystems stehen an zweiter Stelle der Todesursachen, unmittelbar nach Nierenversagen. Epileptische Anfälle sind das am häufigsten beobachtete Symptom (15\%). Rückenmarksschäden sind äussert selten. Bis heute wurde in der Literatur von I 8 Autoren über 26 Fälle berichtet. Die Lebenserwartung der Patienten mit Lupus erythematodes hat sich im Verlaufe des letzten Jahrzehnts merklich gebessert. Dies ist weitgehend auf die diagnostische Früherfassung und die Kombinationstherapie von Kortikosteroiden mit Inhibitoren des Immunsystems zurückzuführen. Patienten mit Nierenversagen werden heute in das 
Dialyseprogramm aufgenommen. Dies bewirkt, dass ein beträchtlicher Anteil von LEPatienten bis in die Spätphase der Krankheit hinein überleben, in welcher Läsionen des Zentralnervensystems besonders häufig sind.

Wir unterstreichen die Bedeutung einer möglichst frühzeitigen Einweisung von Patienten mit Lupus-Myelopathie in eine Spezialabteilung für Rückenmarksgeschädigte, welche über die notwendigen Spezialbetten zur Dekubitusprophylaxe verfügt und in der gleichzeitig ein optimales Rehabilitationsprogramm gewährleistet ist.

Acknowledgement. We wish to thank Dr Y. Radi, medical director, Department of Rheumatology, State Hospital of Fribourg, Switzerland, for having provided us with followup data on case $\mathrm{O}$. Y.

\section{REFERENCES}

Andrews, J. M., Cancilla, P. A. \& Kunin, J. (1970). Progressive spinal cord signs in a patient with disseminated lupus erythematosus. Bull. Los Angeles Neurol. Soc., 35, 78-85.

AndRianAKos, A. A., Duffy, J. \& Suzuki, M. (I975). Transverse myelopathy in systemic lupus erythematosus. Ann. intern. Med., 83, 616-624.

APRIL, R. S. \& VANSONNENBERG, E. (I976). A case of neuromyelitis optica (Devic's syndrome) in systemic lupus erythematosus. Neurology, 26, I066-1070.

Bailey, A. A., Sayre, G. P. \& Clark, E. C. (1956). Neuritis associated with systemic lupus erythematosus. Arch. Neurol. Psychiat., 75, 25 I-259.

Bas, H. \& Vachtenheim, J. (1963). Neurologische Erscheinungen beim systematischen Lupus erythematodes. Dtsch. Zschr. Nervenheilkunde, 185, 244-25I.

Bennahum, D. A., Messner, R. P. \& Shoop, J. D. (1974). Brain scan findings in central nervous system involvement by lupus erythematosus. Seninars Arthritis Rheum., 4, 253-266.

BerRY, R. G. \& Hodges, J. H. (1965). Nervous system involvement in systemic lupus erythematosus. Trans. Am. Neurol., Assoc., 90, 23 I-233.

Brandt, K. D., Lessell, S. \& Cohen, A. S. (1975). Cerebral disorders of vision in systemic lupus erythematosus. Ann. Intern. Med., 83, I63-169.

BRANDT, K. D. \& LesSELL, S. (I978). Migrainous phenomena in systemic lupus erythematosus. Arthritis Rheum., 21, 7-16.

Burton, R., MCDufFie, F. \& MUlDER, D. (I97I). Lupus erythematosus, an autoimmune disease of the nervous system? In: RowLAND (ed.), Immunological disorders of the nervous system. William and Wilkins, Baltimore.

Castaing, G., Vital, C. \& Cardinaud, J. P. (I970). Ramollissement médullaire au cours d'un lupus érythémateux disséminé. Etude anatomo-clinique d'une observation. Bordeaux Med., 3, 707-718.

Cendrowski, W. \& STEPHEN, M. (I974). Clinical variant of lupus erythematosus resembling multiple sclerosis. Europ. Neurol., I I, 373-376.

Clark, E. C. \& BaIley, A. A. (1956). Neurological and psychiatric signs associated with systemic lupus erythematosus. $\mathcal{F} A M A, \mathbf{1 6 0}, 455-457$.

DALY, D. (1945). Central nervous system in acute disseminated lupus erythematosus. F. nerv. ment. Dis., 102, 46I-465.

DuFFy, J., ANDRIANAKOS, A. \& LIDSKY, M. (I974). Low spinal fluid glucose in systemic lupus with spinal cord disease. Clin. Res. 22, 610.

GolD, A. P. \& YAHR, M. D. (I960). Childhood lupus erythematosus; a clinical and pathological study of the neurological manifestations. Trans. Am. Neurol. Assoc., 85, 96-102.

GoldBerg, M. \& ChitanondH, H. (I959). Polyneuritis with albumino-cytologic dissociation in the spinal fluid in systemic lupus erythematosus. Amer. F. Med., 27, 342-350.

GrangER, D. P. (1960). Transverse myelitis with recovery; the only manifestation of systemic lupus erythematosus. Neurology, 10, 325-329.

Hadler, N. M., Gerwin, R. D. \& Frank, M. M. (I973). The fourth component of complement in the cerebrospinal fluid in systemic lupus erythematosus. Arthritis Rheum., I6, 507-520.

Heptinstall, R. H. \& Sowry, G. S。C. (1952). Peripheral neuritis in systemic lupus erythematosus. Brit. Med. F., r, 525-527.

Johnson, R. T. (1962). Neurologic and neuropathologic observations in lupus erythematosus. New Engl. F. Med., 266, 895.

$17 / 3-F$ 
Johnson, R. T. \& Richardson, E. P. (1968). The neurological manifestations of systemic lupus erythematosus. Medicine (Baltimore), 47, 337-369.

Krankenhagen, B., Cohnen, G. \& LehmanN, H. J. (I975). Frühmanifestationen des lupus erythematodes im Zentralnervensystem. Dtsch. Med. Wschr., 45, 2328-2337.

Laguna, J. \& Gravioto, H. (I973). Spinal cord infarction secondary to occlusion of the anterior spinal artery. Arch. Neurol., 28, 134-136.

Levin, A. A., Findenberg, H. J. \& PetZ, L. D. (I972). IgG levels in cerebrospinal fluid of patients with central nervous system manifestations of systemic lupus erythematosus. Clin. Immunol. Immunopathol., I, I-5.

Lipton, H. L. \& TEASDALl, R. D. (I973). Acute transverse myelopathy in adults; a follow-up study. Arch. Neurol., 28, 252-257.

Malamud, N. \& Saver, G. (1954). Neuropathological findings in disseminated lupus erythematosus. A.M.A. Arch. Neurol. Psychiat., 71, 723-731.

O'Connor, J. F. (1959). Psychoses associated with systemic lupus erythematosus. Ann. Intern. Med., 51, 526-529.

O'Connor, J. F. \& Musher, D. M. (I966). Central nervous system involvement in systemic lupus erythematosus. Arch. Neurol., 14, I 57-164.

PenN, A. S. \& Rowan, J. R. (I968). Myelopathy in systemic lupus erythematosus, Arch. Neurol., 18, 337-340.

Petz, L., Sharp, G. C. \& Cooper, N. R. (I97I). Serum and cerebral spinal fluid complement and scrum auto-antibodies in systemic lupus erythematosus. Medicine, 50, 25927I.

PIPER, P. G. (1953). Disseminated lupus erythematosus with involvement of the spinal cord. $\mathcal{F} A M A, \mathbf{1 5 3}, 215^{-217}$.

Russel, P. W., HASERICK, J. R. \& ZuCKer, E. M. (I95I). Epilepsy in systemic lupus erythematosus; effect of cortisone and ACTH. Arch. Intern. Med., 88, 78-92.

SCHEINBERG, L. (1956). Polyneuritis in systemic lupus erythematosus. Review of the literature and report of a case. New Engl. F. Med., 255, 416-42 I.

SEDGWICK, R. P. \& von HAGEN, K. O. (I948). The neurological manifestations of lupus erythematosus and periarteritis nodosa. Bull. Los Angeles Neurol. Soc., 13, I29-142.

SERGENT, J. S., LoCKSHIN, M. D. \& KLEMPNER, M. S. (I975). Central nervous system disease in systemic lupus erythematosus; therapy and prognosis. Am. F. Med., 58, 644-654.

Siekert, R. G. \& ClaRk, E. C. (I955). Neurologic signs and symptoms as early manifestations of systemic lupus erythematosus. Neurology, 5, 84-88.

SilversteIN, A. (1963). Cerebrovascular accidents as the initial major manifestation of lupus erythematosus. N.Y. State F. Med., 63, 2942-2948.

SMall, P., Mass, M. F., Kohler, P. F. \& HarbeCK, R. J. (1977). Central nervous system involvement in SLE. Arthritis Rheum., 20, 869-878.

Stern, M. \& Robbins, E. S. (I960). Psychoses in systemic lupus erythematosus. Arch. Gen. Psychiat., 3, 205-212.

Veron, J. P., Escourolle, R. \& Buge, A. (1974). Acute necrotic myelopathy. Europ. Neurol., II, 83-96.

WeIL, M. H. (I955). Disseminated lupus erythematosus with massive hemorrhagic manifestations and paraplegia. Lancet, 75, 358-360. 